\title{
On the Current and Restoration Conditions of the Southern Iraqi Marshes: Application of the CCME WQI on East Hammar Marsh
}

\author{
Azhar Al-Saboonchi ${ }^{1}$, Abdul-Razak M. Mohamed ${ }^{1}$, Abdul Hameed M. Jawad Alobaidy', \\ Haider S. Abid ${ }^{3}$, Bahram K. Maulood ${ }^{4}$ \\ ${ }^{1}$ Department of Fisheries and Marine Resources, University of Basrah, Basrah, Iraq; ${ }^{2}$ Environmental Research Center, University of \\ Technology, Baghdad, Iraq; ${ }^{3}$ Department of Biology, College of Science for Women, University of Baghdad, Baghdad, Iraq; ${ }^{4}$ Twin \\ Rivers Institute, American University of Iraq-Sulaimani, Sulaimani, Iraq. \\ Email: azharalsaboonchi@yahoo.com, abdul19532001@yahoo.com,jawaddhy@yahoo.co.in, haider.abid@gmail.com, \\ bahram.khider@auis.org
}

Received January $9^{\text {th }}, 2011$; revised February $17^{\text {th }}, 2011$; accepted March $26^{\text {th }}, 2011$.

\begin{abstract}
Water quality of the East Hammar marsh after restoration was assessed by using the Canadian Council of Ministers of the Environment Water Quality Index (CCME WQI). The model was applied in two approaches based on the historical data and the CCME aquatic life guidelines as objectives. Variables included in the index calculation were Water Temperature, Dissolved Oxygen, Salinity, $\mathrm{pH}$ value, Total Nitrogen, Ammonia, Nitrate, Phosphorus and Sodium. The CCME WQI analysis in both approaches reflected that water quality of the East Hammar marsh is rated as poor based on 2005-2006 data, meaning that the conditions of the marsh are often depart from natural or desirable levels particularly in respect to sodium and nitrogenous compounds; it simply has not recovered yet. The results reflect that the marsh area is still far from the current guideline criteria and, too far from restoration.
\end{abstract}

Keywords: WQI, Iraqi Marshes, Restoration, Nature Iraq

\section{Introduction}

Water is an essential natural resource for sustaining life and environment, which is always thought to be available in abundance and free gift of nature. With the increase of living population it has been put under tremendous pressure due to human and other biological activities [1]. Within an aquatic ecosystem, a complex interaction of physical and biochemical cycles exists, anthropogenic stresses, particularly the interaction of chemicals into water may adversely affect many species of aquatic flora and fauna. Water quality criteria for protection of aquatic life may take into account only physic-chemical parameters which tend to protect and maintain aquatic life [2].

East Hammar marsh is situated south of the Euphrates, extending from near Nasiriyah in the west to the outskirts of Basrah on the Shatt al-Arab in the east (Figure 1). The marsh area historically consisted of $2800 \mathrm{~km}^{2}$ of permanent marsh and lake, expanding to more than 4500 $\mathrm{km}^{2}$ during periods of seasonal and temporary inundation. Hammar marsh is the largest water body on the lower
Euphrates. In the late 1980s, it was approximately 120 $\mathrm{km}$ long and $25 \mathrm{~km}$ wide. Maximum water depth in the lake ranged from 1.8 to $3 \mathrm{~m} \mathrm{[3]}$.

During the 1990s, the East Hammar marsh completely dried out as a result of local drainage structures built throughout government policy. These structures included two dams on the Euphrates, one at Nasiriyah and one at Medina to reduce water flow into the marsh area; sluice gates and dams placed on distributaries of the Euphrates to restrict water flow; and two canals and a pipeline that diverted water from the Euphrates and agricultural drainage water away from the marshlands. In 2002, only $14.5 \%$ of the East Hammar marshes remained [4]. In 2003 and 2004, the local Marsh dwellers and Iraq's Ministry of Water Resources began to divert water back into the marshlands through opening sluice gates, breaching embankments, and other actions along the southern side (Garmat Ali marsh). Water from the Euphrates is returning from the western and northern sides of Hammar and from Shatt al-Arab through Garmat Ali to the southeast. As of August 2005, the marshes had recovered almost 
$40 \%$ of their former levels, according to UNEP. Satellite imagery shows the southern marshlands now occupy about $3500 \mathrm{~km}^{2}$ after having dwindled to just $760 \mathrm{~km}^{2}$.

The case of marshlands should be considered as one of the unique ecosystems which had been deliberately dried up for more than a decade. Ultimately, the whole ecosystem demolished. However, after 2003 the policy was to restore the marshes again. Therefore, continuous monitoring and ecological studies were among the main tools to follow up the restoration process and monitoring the successive improvement of the status of the area. Such a phenomenon urged the application of new tools to analyze the large amount of data collected through the monitor surveys. There is considerable debate as to which measure should be included in the derivation of an index for water quality [5]. Despite the debate, there is some agreement that water quality indices (WQIs) are useful tools for comparing water quality across systems and overtime. They can provide a benchmark for evaluating successes and failures of management strategies aimed at improving water quality [6].

WQI is a tool that is increasingly used to solve such problems of data management in different areas in the world. A number of indices have been developed to summarize water quality data in an easily expressible and easily understood format [1,7-11]. In general, water quality indices incorporate data from multiple water quality parameters into a mathematical equation that rates the health of ecosystem with a single number. That number is placed on a relative scale to justify the water quality in categories ranging from very bad to excellent. This number can be easily interpreted and understood by political decision-makers, non-technical water managers, and the general publics.

Among the developed models was that informed by the Canadian Council of Ministers of the Environment (CCME). The CCME WQI is based on a formula developed by the British Columbia Ministry of Environment, Lands and Parks that was modified by Alberta Environment, Canada. This index doesn't give any weighted numbers but treats the values of parameters in mathematical ways to ensure that all parameters contribute adequately in the final number of the index. This model is flexible, allowing one to choose the parameters to use and standardize them according to the objectives and area of study [9].

One of the new projects adopted by Nature Iraq (NI) in early 2008 is the Data Indices Project. In July 2008, NI in cooperation with Iraqi experts in the field of environmental research from different Iraqi universities and institutes discussed a scheme in which the data collected can be easily summarized and converted into an index or indices digested by scientists as well as decision makers. The experts suggested starting a new task that aims at standardization of the methods used all over Iraq and apply the models of the Water Quality Index (WQI) and the Indices of Biological Integrity (IBI) to study the different hydrological and biological aspects of aquatic environments.

In this study, the CCME WQI has been applied in two approaches, one in respect to historical data and the second based on the Canadian guidelines for the protection of aquatic life. Such an attempt is applied for the first time in Iraq to evaluate the water quality in the marshes after restoration.

\section{Materials and Methods}

The data of ARID [12] and Tahir et al. [13] which were collected after restoration are used in the present study (Table 1). Water measurements were made monthly from two selected sites in the East Hammar (Figure 1): The Saddah site $\left(30^{\circ} 40^{\prime} 04^{\prime \prime} \mathrm{N}, 4^{\circ} 38^{\prime} 06^{\prime \prime} \mathrm{E}\right)$, represents a natural marsh environment and Burkah site $\left(30^{\circ} 40^{\prime} 22^{\prime \prime} \mathrm{N}\right.$, $\left.47^{\circ} 33^{\prime} 03^{\prime \prime} \mathrm{E}\right)$ was previously desiccated, but it is now open shallow water with scattered islands of Typha domingensis and Myrophyllum verticillatum. The period examined is eleven months (September, 2005 to July, 2006) and the sampling frequency at these sites is monthly for all variables.

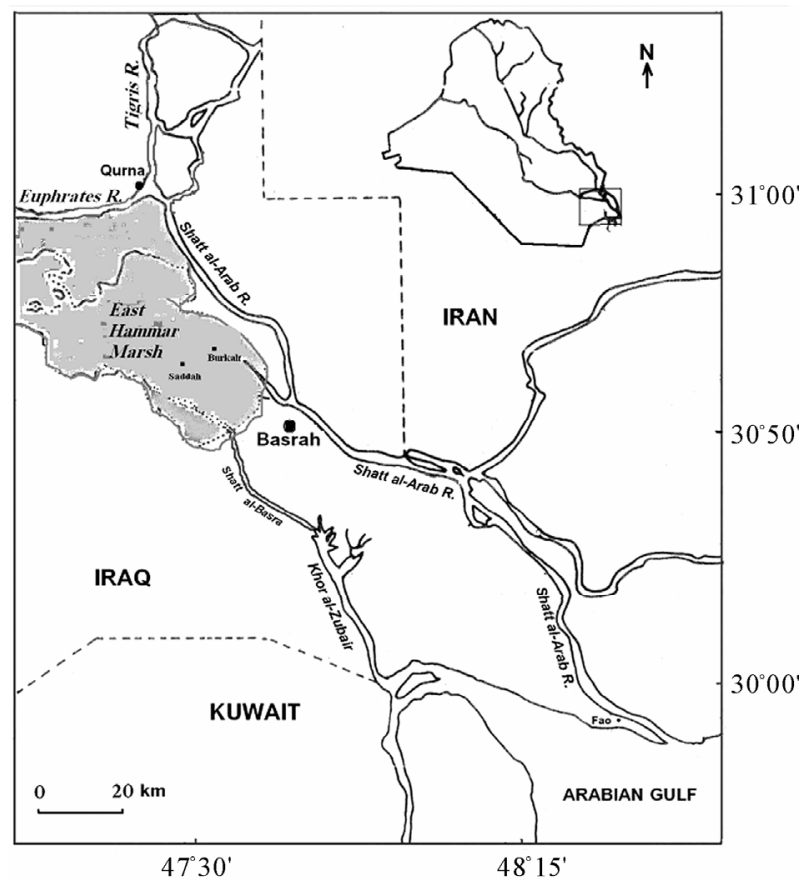

Figure 1. Map of the East Hammar Marsh, south Iraq illustrating the study sites. 
In this study, the CCME Water Quality Index was applied and tested for the East Hammar marsh using two types of criteria. First, historical published data before the drainage [14-19] (referred to as objective in Table 1). This model was called as the Restoration-Based CCME WQI since it compares the data collected after restoration to the historical data. For this analysis, index scores were determined for nine constituents (Table 1): Water Temp., DO, Salinity, $\mathrm{pH}, \mathrm{TN}, \mathrm{NH}_{4}-\mathrm{N}, \mathrm{NO}_{3}-\mathrm{N}, \mathrm{PO}_{4}-\mathrm{P}$ and $\mathrm{Na}^{+}$. Second, the CCME guidelines for the protection of aquatic life [20] (referred to as objective in Table 2) and this model was referred to as the Guidelines-Based CCME WQI since it compares the same recent data to the current Canadian guidelines. For this analysis, index scores were determined for eight constituents (Table 2): Water Temp., DO, pH, TN, $\mathrm{NH}_{4}-\mathrm{N}, \mathrm{NO}_{3}-\mathrm{N}, \mathrm{PO}_{4}-\mathrm{P}$ and $\mathrm{Na}^{+}$.

Essentially, the CCME WQI model consists of three measures of variance from selected water quality objectives (Scope; Frequency; Amplitude). The "Scope $\left(F_{1}\right)$ " represents the extent of water quality guideline non-compliance over the time period of interest. The "Frequency $\left(F_{2}\right)$ " represents the percentage of individual tests that do not meet objectives ("failed tests"). The "Amplitude $\left(\mathrm{F}_{3}\right)$ " represents the amount by which failed tests do not meet their objectives. These three factors combine to produce a value between 0 and 100 that represents the overall water quality. The formulation of the WQI as described in the Canadian Water Quality Index $1.0-$ Technical Report is as follows [9]. The measure for scope is $F_{1}$ which is calculated as follows:

$$
F_{1}=\frac{\text { Number of failed variables }}{\text { Total number of variables }} \times 100
$$

The measure for frequency is $F_{2}$ which is calculated as follows:

$$
F_{2}=\frac{\text { Number of failed tests }}{\text { Total number of tests }} \times 100
$$

The measure for amplitude is $F_{3}$. This is calculated in three steps:

1) Excursion is the number of times by which an individual concentration is greater than (or less than, when the objective is a minimum) the objective.

When the test value must not exceed the objective:

$$
\text { excursion }_{i}=\left(\frac{\text { Failed test value }_{i}}{\text { Objective }_{j}}\right)-1
$$

When the test value must not fall below the objective:

$$
\text { excursion }_{i}=\left(\frac{\text { Objective }_{j}}{\text { Failed test value }_{i}}\right)-1
$$

2) The normalized sum of excursions, nse, is the collective amount by which individual tests are out of compliance. This is calculated by summing the excursions of individual tests from their objectives and dividing by the total number of tests (both those meeting objectives and those not meeting objectives).

$$
\text { nse }=\left[\sum_{i=}^{n} \text { excurison }(i)\right] \div \text { Number of tests }
$$

3) $F_{3}$ is calculated by an asymptotic function that scales the normalized sum of the excursions from objectives to yield a range from 0 to 100 .

$$
F_{3}=\frac{n s e}{0.01 \times n s e+0.01}
$$

The WQI is then calculated as:

$$
W Q I=100-\left(\frac{\sqrt{F_{1}^{2}+F_{2}^{2}+F_{3}^{2}}}{1.732}\right)
$$

This score is then ranked into one of the following five categories: excellent (WQI $=95-100)$, good $(\mathrm{WQI}=$ 80 - 94), fair (WQI = 65 - 79), marginal (WQI = $45-64)$ and poor $(\mathrm{WQI}=0-44)$.

\section{Results}

\subsection{Restoration-Based CCME WQI Analysis}

By applying the equations in the materials and methods section above, the values of $F_{1}$ and $F_{2}$ were 88.89 and 62.63, respectively. (Table 2; bolded values represent variables not meeting the objectives). The (nse) value was calculated to be 3.07 while $F_{3}$ value was 75.43 (Table 3).

Once the factors have been obtained, the index itself could be calculated by summing the three factors as if they were vectors. The sum of the squares of each factor is therefore equal to the square of the index. This approach treats the index as a three-dimensional space defined by each factor along one axis. With this model, the index changes in direct proportion to changes in all three factors. Accordingly, the final WQI value was calculated to be 23.60 , which reflect poor water quality conditions.

\subsection{Guideline-Based CCME WQI Analysis}

For this analysis, the values of $F_{1}$ and $F_{2}$ were 37.5 and 38.64 , respectively. The value of nse was 710.53 and, hence, $F_{3}$ value was found to be 99.86 (Table 4). The overall WQI value was 34.49 which also an indicator of poor water quality conditions in this area. 

the CCME WQI on East Hammar Marsh

Table 1. Physical and chemical properties of water at East Hammar Marsh during 2005-2006 as compared to the historical objectives.

\begin{tabular}{cccccccccc}
\hline Date & $\begin{array}{c}\text { Water Temp } \\
\left({ }^{\circ} \mathrm{C}\right)\end{array}$ & $\begin{array}{c}\mathrm{DO} \\
(\mathrm{mg} / \mathrm{L})\end{array}$ & $\begin{array}{c}\text { Salinity } \\
\left(\%{ }_{0}\right)\end{array}$ & $\mathrm{pH}$ & $\begin{array}{c}\mathrm{TN} \\
(\mathrm{mg} / \mathrm{L})\end{array}$ & $\begin{array}{c}\mathrm{NH}_{4}-\mathrm{N} \\
(\mathrm{mg} / \mathrm{L})\end{array}$ & $\begin{array}{c}\mathrm{NO}_{3}-\mathrm{N} \\
(\mu \mathrm{g} / \mathrm{L})\end{array}$ & $\begin{array}{c}\mathrm{PO}-\mathrm{P} \\
(\mu \mathrm{g} / \mathrm{L})\end{array}$ & $\begin{array}{c}\mathrm{Na} \\
(\mathrm{mg} / \mathrm{L})\end{array}$ \\
\hline Sept. 05 & 26.93 & 8.50 & $\mathbf{2 . 0 5}$ & 8.10 & $\mathbf{2 . 1 0}$ & $\mathbf{0 . 9 5}$ & $\mathbf{2 2 . 0 0}$ & 0.51 & $\mathbf{3 9 4 . 5}$ \\
Oct. 05 & 24.10 & 9.15 & $\mathbf{1 . 7 9}$ & 7.95 & $\mathbf{2 . 8 2}$ & $\mathbf{0 . 8 5}$ & $\mathbf{2 7 . 7 0}$ & $\mathbf{0 . 7 7}$ & $\mathbf{3 6 3 . 5}$ \\
Nov. 05 & 23.66 & 11.25 & 1.44 & 7.83 & $\mathbf{3 . 8 6}$ & $\mathbf{0 . 5 1}$ & $\mathbf{3 1 . 7 5}$ & $\mathbf{0 . 8 5}$ & $\mathbf{3 4 1 . 9}$ \\
Dec. 05 & $\mathbf{1 7 . 6 5}$ & 11.70 & 1.35 & 7.80 & $\mathbf{4 . 1 0}$ & $\mathbf{0 . 4 7}$ & $\mathbf{3 4 . 0 0}$ & $\mathbf{0 . 8 8}$ & $\mathbf{3 1 0 . 5}$ \\
Jan. 06 & $\mathbf{1 6 . 1 0}$ & 12.03 & 1.15 & 7.70 & $\mathbf{4 . 4 0}$ & $\mathbf{0 . 4 0}$ & $\mathbf{2 9 . 8 0}$ & $\mathbf{0 . 9 3}$ & $\mathbf{2 8 0 . 5}$ \\
Feb. 06 & $\mathbf{1 7 . 2 0}$ & 11.15 & 1.35 & 7.80 & $\mathbf{3 . 5 0}$ & $\mathbf{0 . 4 5}$ & $\mathbf{2 5 . 1 0}$ & $\mathbf{0 . 6 5}$ & $\mathbf{2 9 5 . 0}$ \\
Mar. 06 & $\mathbf{1 9 . 6 5}$ & 10.15 & 1.60 & 7.80 & $\mathbf{2 . 7 0}$ & $\mathbf{0 . 5 8}$ & $\mathbf{2 1 . 5 8}$ & 0.46 & $\mathbf{3 1 0 . 0}$ \\
Apr. 06 & $\mathbf{2 2 . 6 5}$ & 9.00 & $\mathbf{1 . 8 5}$ & 7.90 & $\mathbf{2 . 2 5}$ & $\mathbf{0 . 6 8}$ & $\mathbf{1 9 . 9 0}$ & 0.36 & $\mathbf{3 4 0 . 0}$ \\
May 06 & 26.70 & 7.95 & $\mathbf{2 . 2 0}$ & 7.90 & $\mathbf{1 . 7 0}$ & $\mathbf{0 . 9 3}$ & $\mathbf{1 6 . 8 5}$ & 0.39 & $\mathbf{3 6 5 . 5}$ \\
Jun. 06 & 28.45 & 6.95 & $\mathbf{2 . 5 5}$ & 8.10 & $\mathbf{1 . 3 5}$ & $\mathbf{2 . 4 0}$ & $\mathbf{2 3 . 8 5}$ & 0.49 & $\mathbf{3 8 2 . 0}$ \\
Jul. 06 & 32.45 & $\mathbf{6 . 4 0}$ & $\mathbf{2 . 9 0}$ & 8.15 & $\mathbf{0 . 9 6}$ & $\mathbf{3 . 7 0}$ & $\mathbf{3 3 . 9 5}$ & $\mathbf{0 . 6 0}$ & $\mathbf{4 0 0 . 0}$ \\
Objectives & 22.67 & 6.90 & 1.70 & $7.1-8.3$ & 0.935 & 0.05 & 5.71 & 0.52 & 161.0 \\
\hline
\end{tabular}

Bolded values do not meet the objectives

Table 2. Physical and chemical properties of water at East Hammar Marsh during 2005-2006 as compared to the CCME guidelines for a quatic life objectives.

\begin{tabular}{ccccccccc}
\hline Date & $\begin{array}{c}\text { Water Temp } \\
\left({ }^{\circ} \mathrm{C}\right)\end{array}$ & $\begin{array}{c}\mathrm{DO} \\
(\mathrm{mg} / \mathrm{L})\end{array}$ & $\mathrm{pH}$ & $\begin{array}{c}\mathrm{TN} \\
(\mathrm{mg} / \mathrm{L})\end{array}$ & $\begin{array}{c}\mathrm{NH}_{4}-\mathrm{N} \\
(\mathrm{mg} / \mathrm{L})\end{array}$ & $\begin{array}{c}\mathrm{NO}_{3}-\mathrm{N} \\
(\mu \mathrm{g} / \mathrm{L})\end{array}$ & $\begin{array}{c}\mathrm{PO}_{4}-\mathrm{P} \\
(\mu \mathrm{g} / \mathrm{L})\end{array}$ & $\begin{array}{c}\mathrm{Na}^{2} \\
(\mathrm{mg} / \mathrm{L})\end{array}$ \\
\hline Sept. 05 & 26.93 & 8.50 & 8.10 & 2.10 & $\mathbf{0 . 9 5}$ & $\mathbf{2 2 . 0 0}$ & 0.51 & $\mathbf{3 9 4 . 5}$ \\
Oct. 05 & 24.10 & 9.15 & 7.95 & 2.82 & $\mathbf{0 . 8 5}$ & $\mathbf{2 7 . 7 0}$ & 0.77 & $\mathbf{3 6 3 . 5}$ \\
Nov. 05 & 23.66 & 11.25 & 7.83 & 3.86 & $\mathbf{0 . 5 1}$ & $\mathbf{3 1 . 7 5}$ & 0.85 & $\mathbf{3 4 1 . 9}$ \\
Dec. 05 & 17.65 & 11.70 & 7.80 & 4.10 & $\mathbf{0 . 4 7}$ & $\mathbf{3 4 . 0 0}$ & 0.88 & $\mathbf{3 1 0 . 5}$ \\
Jan. 06 & 16.10 & 12.03 & 7.70 & 4.40 & $\mathbf{0 . 4 0}$ & $\mathbf{2 9 . 8 0}$ & 0.93 & $\mathbf{2 8 0 . 5}$ \\
Feb. 06 & 17.20 & 11.15 & 7.80 & 3.50 & $\mathbf{0 . 4 5}$ & $\mathbf{2 5 . 1 0}$ & 0.65 & $\mathbf{2 9 5 . 0}$ \\
Mar. 06 & 19.65 & 10.15 & 7.80 & 2.70 & $\mathbf{0 . 5 8}$ & $\mathbf{2 1 . 5 8}$ & 0.46 & $\mathbf{3 1 0 . 0}$ \\
Apr. 06 & 22.65 & 9.00 & 7.90 & 2.25 & $\mathbf{0 . 6 8}$ & $\mathbf{1 9 . 9 0}$ & 0.36 & $\mathbf{3 4 0 . 0}$ \\
May 06 & 26.70 & 7.95 & 7.90 & 1.70 & $\mathbf{0 . 9 3}$ & $\mathbf{1 6 . 8 5}$ & 0.39 & $\mathbf{3 6 5 . 5}$ \\
Jun. 06 & 28.45 & 6.95 & 8.10 & 1.35 & $\mathbf{2 . 4 0}$ & $\mathbf{2 3 . 8 5}$ & 0.49 & $\mathbf{3 8 2 . 0}$ \\
Jul. 06 & 32.45 & 6.40 & 8.15 & $\mathbf{0 . 9 6}$ & $\mathbf{3 . 7 0}$ & $\mathbf{3 3 . 9 5}$ & 0.60 & $\mathbf{4 0 0 . 0}$ \\
Objectives & 15.00 & 5.00 & $6.5-9$ & 1.00 & 0.016 & 2930 & 100 & 0.062 \\
\hline
\end{tabular}

Bolded values do not meet the objectives 
Table 3. Excursion values for the parameters applied to the restoration-based WQI for East Hammar Marsh.

\begin{tabular}{cccccccccc}
\hline Date & $\begin{array}{c}\text { Water Temp } \\
\left({ }^{\circ} \mathrm{C}\right)\end{array}$ & $\begin{array}{c}\mathrm{DO} \\
(\mathrm{mg} / \mathrm{L})\end{array}$ & $\begin{array}{c}\text { Salinity } \\
\left(\%{ }_{0}\right)\end{array}$ & $\mathrm{pH}$ & $\begin{array}{c}\mathrm{TN} \\
(\mathrm{mg} / \mathrm{L})\end{array}$ & $\begin{array}{c}\mathrm{NH}_{4}-\mathrm{N} \\
(\mathrm{mg} / \mathrm{L})\end{array}$ & $\begin{array}{c}\mathrm{NO}_{3}-\mathrm{N} \\
(\mu \mathrm{g} / \mathrm{L})\end{array}$ & $\begin{array}{c}\mathrm{PO}_{4}-\mathrm{P} \\
(\mu \mathrm{g} / \mathrm{L})\end{array}$ & $\begin{array}{c}\mathrm{Na} \\
(\mathrm{mg} / \mathrm{L})\end{array}$ \\
\hline Sept. 05 & - & - & 0.205882 & - & 1.245989 & 18.0 & 2.85289 & - & 1.450311 \\
Oct. 05 & - & - & 0.052941 & - & 2.016043 & 16.0 & 3.851138 & 0.480769 & 1.257764 \\
Nov. 05 & - & - & - & - & 3.128342 & 9.2 & 4.56042 & 0.634615 & 1.123602 \\
Dec. 05 & -0.22144 & - & - & - & 3.385027 & 8.4 & 4.954466 & 0.692308 & 0.928571 \\
Jan. 06 & -0.28981 & - & - & - & 3.705882 & 7.0 & 4.218914 & 0.7888462 & 0.742236 \\
Feb. 06 & -0.24129 & - & - & - & 2.743316 & 8.0 & 3.395797 & 0.25 & 0.832298 \\
Mar. 06 & -0.13322 & - & - & - & 1.887701 & 10.6 & 2.779335 & - & 0.925466 \\
Apr. 06 & -0.00088 & - & 0.088235 & - & 1.406417 & 12.6 & 2.485114 & - & 1.111801 \\
May 06 & - & - & 0.294118 & - & 0.818182 & 17.6 & 1.950963 & - & 1.270186 \\
Jun. 06 & - & - & 0.5 & - & 0.44385 & 47.0 & 3.176883 & - & 1.372671 \\
Jul. 06 & - & 0.078125 & 0.705882 & - & 0.026738 & 73.0 & 4.945709 & 0.153846 & 1.484472 \\
\hline
\end{tabular}

Table 4. Excursion values for the parameters applied to the guidelines-based WQI for East Hammar Marsh.

\begin{tabular}{|c|c|c|c|c|c|c|c|c|}
\hline Date & $\begin{array}{l}\text { Water Temp } \\
\quad\left({ }^{\circ} \mathrm{C}\right)\end{array}$ & $\begin{array}{c}\mathrm{DO} \\
(\mathrm{mg} / \mathrm{L})\end{array}$ & $\mathrm{pH}$ & $\begin{array}{c}\mathrm{TN} \\
(\mathrm{mg} / \mathrm{L})\end{array}$ & $\begin{array}{l}\mathrm{NH}_{4}-\mathrm{N} \\
(\mathrm{mg} / \mathrm{L})\end{array}$ & $\begin{array}{l}\mathrm{NO}_{3}-\mathrm{N} \\
(\mu \mathrm{g} / \mathrm{L})\end{array}$ & $\begin{array}{l}\mathrm{PO}_{4}-\mathrm{P} \\
(\mu \mathrm{g} / \mathrm{L})\end{array}$ & $\begin{array}{c}\mathrm{Na} \\
(\mathrm{mg} / \mathrm{L})\end{array}$ \\
\hline Sept. 05 & - & - & - & - & 58.375 & -0.99249 & - & 6361.903 \\
\hline Oct. 05 & - & - & - & - & 52.125 & -0.99055 & - & 5861.903 \\
\hline Nov. 05 & - & - & - & - & 30.875 & -0.98916 & - & 5513.516 \\
\hline Dec. 05 & - & - & - & - & 28.375 & -0.98840 & - & 5007.065 \\
\hline Jan. 06 & - & - & - & - & 24.000 & -0.98983 & - & 4523.194 \\
\hline Feb. 06 & - & - & - & - & 27.125 & -0.99143 & - & 4757.065 \\
\hline Mar. 06 & - & - & - & - & 35.250 & -0.99263 & - & 4999 \\
\hline Apr. 06 & - & - & - & - & 41.500 & -0.99321 & - & 5482.871 \\
\hline May 06 & - & - & - & - & 57.125 & -0.99425 & - & 5894.161 \\
\hline Jun. 06 & - & - & - & - & 149.000 & -0.99186 & - & 6160.29 \\
\hline Jul. 06 & - & - & - & -0.04 & 230.25 & -0.98841 & - & 6450.613 \\
\hline
\end{tabular}

\section{Discussion}

Although our results showed that the Guidelines-Based CCME WQI value was almost double of that for the Restoration-Based CCME WQI, the conditions of the marsh were still often departing from natural or desirable levels; it simply has not recovered yet and remained in poor condition in respect to the parameters under consideration in this paper.

The outcome of this investigation shows that the pa- rameters of concern to the restoration-based WQI (Table 1) are $\mathrm{TN}, \mathrm{NH}_{4}-\mathrm{N}$ and $\mathrm{Na}^{+}$ions concentrations that consistently exceeded the objectives, whereas $\mathrm{PO}_{4}$, salinity and water temperature occasionally exceeded the objectives. However, DO concentration was out of the objective in one occasion only, during July 2006. In contrast, Table 2 in which the objective depends on the CCME guidelines shows that $\mathrm{NH}_{4}-\mathrm{N}, \mathrm{NO}_{3}-\mathrm{N}$ and $\mathrm{Na}$ consistently exceeded the objective, whereas $\mathrm{TN}$ was the only parameter that occasionally exceeded the objective. 
Overall, the conditions of the marsh in respect to supporting current life (fauna and flora) are better when compared with those conditions related to meeting the restoration targets. However, more efforts are needed to recover the area, particularly with regard to $\mathrm{Na}$ and $\mathrm{TN}$ as well as salinity levels.

It is evident from the results that water properties in the marshlands have passed through a great degradation process throughout the deliberately drying process which took more than a decade. This phenomenon clearly reflects its effects on the aquatic life in the area, physical, chemical and biological-wise. However, the composition and balance of the elements in the water has strongly altered, chemical characters known previously in the marshes $[15,16,21,22]$ is not evident any more. Nitrogen compounds vigorously increased, phosphate levels clearly decreased, salinity strongly increased, sodium became the dominant cation in parallel with calcium and magnesium, and conductivity doubled as indicated by Fitzpatrick [23].

Furthermore, many areas of the marshes were severely burned after drainage. The intensity of the burns in some areas, with high surface organic matter covering sulfidic pyrite soils beneath, resulted in soils being greatly altered chemically [23]. Richardson et al. [24] noted that water chemistry values of Hammar marsh, when compared with historical surveys completed before drainage $[22,25]$, revealed high increases in the concentrations of several ions including $\mathrm{Na}$ which was raised by $(170 \%)$ in the Suq Al-Shuyukh region during the past 20 years. Richardson \& Hussain [4] stated that the reflooded East Al-Hammar had highest total phosphates and nitrogen compared with other marshes, which may be related to sampling at several sites where human and animal waste was released directly into the water column without treatment. Also, this is probably relates to a rise in salinity in the Euphrates and to increased flux into the water column of ions concentrated in the soil after 10 years of drainage and evaporation.

The outcomes of application of the CCME WQI in the present study came in accordance with the above mentioned results, using both the two approaches. Therefore, one will not hesitate to state the urgent need to restore the area; plantation, increasing water flow, sustainable management, strong and firm policy are among the most needed measures to recover the marshes.

These results can be of a great value for water users and planners to depend upon for restoration of the marshes that undoubtedly need more effort and time as well as wise judgment.

\section{Acknowledgements}

Many thanks to Nature Iraq and Twin River Institute, American University of Iraq-Sulaimani, without their financial support the work would have not been done.

\section{REFERENCES}

[1] M. B. Chougule, A. I. Wasif and V. R. Naik, "Assessment of Water Quality Index (WQI) for Monitoring Pollution of River Panchganga at Ichalkaranji," Proceedings of International Conference on Energy and environment, Chandigarh, March 2009, pp. 122-127.

[2] UNECE, "Standard Statistical Classification of Surface Freshwater Quality for the Maintenance of Aquatic Life," In: Readings in International Environment Statistics, United Nations Economic Commission for Europe, United Nations, New York and Geneva, 1994.

[3] H. Partow, "The Mesopotamian Marshlands: Demise of an Ecosystem," Division of Early Warning and Assessment, United Nations Environment Programme, UNEP Publication UNEP/DEWA/ TR.01-3. Nairobi, Kenya, 2001.

[4] C. J. Richardson and N. A. Hussain, "Restoring the Garden of Eden: An Ecological Assessment of the Marshes of Iraq," BioScience, Vol. 56, No. 6, June 2006, pp. 477-489. doi:10.1641/0006-3568(2006)56[477:RTGOEA]2.0.CO;2

[5] S. Harkness, "Social and Political Indicators of Human Well-Being," United Nations University, World Institute for Development Economics Research, Research Paper No. 33, 2004, pp. 1-22.

[6] C. J. Rickwood and G. M. Carr, "Development and Sensitivity Analysis of a Global Drinking Water Quality Index," Environmental Monitoring and Assessment, Vol. 156, No. 1-4, September 2009, pp. 73-90. doi:10.1007/s10661-008-0464-6

[7] R. D. Harkins, "An Objective Water Quality Index," Journal of Water Pollution Control Federation, Vol. 46, No. 5, July 1974, pp. 588-591.

[8] D. Couillard and Y. Lefebvre, "Analysis of Water Quality Indices," Journal of Environmental Management, Vol. 21, No. 2, 1985, pp. 161-179.

[9] Canadian Council of Ministries of the Environment (CCMC), "Canadian Water Quality Index 1.0 Technical Report and User's Manual," Canadian Environmental Quality Guidelines, Technical Subcommittee, Gatineau, 2001.

[10] C. Cude, "Oregon Water Quality Index: A Tool for Evaluating Water Quality Management Effectiveness," Journal of American Water Resource Association, Vol. 37, No. 1, February 2001, pp. 125-137. doi:10.1111/j.1752-1688.2001.tb05480.x

[11] D. Hallock, "Water Quality Assessment of the Nooksack River between Brennan and North Cedarville," Technical Report, Washington Department of Ecology, Environmental Assessment Program, 2002. 
[12] ARID, "Agriculture Reconstruction and Development Program for Marshlands Monitoring," Final Report, 20052006, University of Basrah, Basrah, 2006.

[13] M. A. Tahir, A. K. Risen and N. A. Hussain, "Monthly Variations in the Physical and Chemical Properties of the Restored Southern Iraqi Marshes," Marsh Bulletin, Vol. 3, No. 1, 2008, pp. 81-94.

[14] B. K. Maulood, G. C. F. Hinton, H. S. Kamees, F. A. K. Saleh, A. A. Shaban, S. M. H. Al-Shahwani, "An Ecological Survey of Some Aquatic Ecosystems in Southern Iraq," Tropical Ecology, Vol. 20, No. 1, 1979, pp. 27-40.

[15] A. M. Al-Zubaidi, "Ecological Study on the Algae (Phytoplankton) in Some Marshes near Qurna-Southern Iraq," M.Sc. Thesis, University of Basrah, Basrah, 1985.

[16] A. A. Al-Lami, "An Ecological Study on the Phytoplankton in the Southern, Iraq," M.Sc. Thesis, University of Basrah, Basrah, 1986.

[17] M. J. Al-A'arjy, "An Ecological Study on Phytoplankton and Nutrients in Al-Hammar Marsh-Iraq," M.Sc. Thesis, University of Basrah, Basrah, 1988.

[18] T. I. Kassim, "An Ecological Study of Benthic Algae in Some Marshes-Southern, Iraq," M. Sc. Thesis, University of Basrah, Basrah, 1986.

[19] A. R. M. Mohamed and N. A. Barak, "Seasonal Variations in Some Limnological Features of the Garma Marshes," Basrah Journal of Agricultural Science, Vol. 1, No. 1, 1988, pp. 56-63.
[20] Canadian Council of Ministries of the Environment (CCMC), "Canadian Water Quality Guidelines for the Protection of Aquatic Life," Canadian Environmental Quality Guidelines, Technical Subcommittee, Gatineau, 1999.

[21] J. Rozoska, "Euphrates and Tigris Mesopotamian Ecology and Destiny," In: Monographiae Biologicae, Dr. Junk, the Hague-Boston-London, 1980.

[22] B. K. Maulood, G. C. F. Hinton, B. A. Whitton and H. A. Al-Saadi, "On the Algal Ecology of the Lowland IraqiMarshes," Hydrobiologia, Vol. 80, No. 3, June 1981, pp. 269-276. doi:10.1007/BF00018367

[23] R. W. Fitzpatrick, "Changes in Soil and Water Characteristics of Some Natural, Drained and Reflooded Soils in the Mesopotamian Marshlands: Implications for Land Management Planning," CSIRO Land and Water Client Report, CSIRO, Clayton, 2004.

[24] C. J. Richardson, P. Reiss, N. A. Hussain, A. J. Alwash and D. J. Pool, "The Restoration Potential of the Mesopotamian Marshes of Iraq," Science, Vol. 307, No. 5713, February 2005, pp. 1307-1311. doi:10.1126/science. 1105750

[25] K. M. Banat, F. M. Howari and M. B. Abdullah, "Mineralogy and Hydrochemical Characteristics of the Late Marshes and Swamps of Hor Al-Hammar, Southern Iraq," Journal of Arid Environments, Vol. 65, No. 3, May 2006, pp. 400-419. doi:10.1016/i.jaridenv.2005.08.004 